\title{
Rhinocerebral and rhinopharyngeal conidiobolomycosis in sheep
}

\author{
Conidiobolomicose rinocerebral e rinofaríngea em ovinos
}

\author{
Antônio Carlos Lopes Câmara ${ }^{\mathrm{I}}$ Benito Soto-Blanco $^{\mathrm{I} *}$ Jael Soares Batista ${ }^{\mathrm{I}}$ \\ André Menezes do Vale ${ }^{\mathrm{I}}$ Francisco Marlon Carneiro Feijó ${ }^{\mathrm{I}}$ Robério Gomes Olinda ${ }^{\mathrm{I}}$
}

\begin{abstract}
The present study aimed to report the occurrence as well as the clinical, laboratorial, pathological and mycological findings of three outbreaks of rhinocerebral and rhinopharyngeal conidiobolomycosis in sheep from Rio Grande do Norte state, Brazil. A total of six sheep with clinical signs of conidiobolomycosis were evaluated, and information on history was obtained from ranchers. Clinical signs included depression, progressive emaciation, sero-sanguinolent nasal discharge, tachycardia, dyspnea, miosis and unilateral exophthalmia with increased ocular globe volume, corneal ulceration and nervous system signs. The main hematological alteration was neutrophilia. Serum biochemical evaluation revealed increased values for AST, GGT, creatinine, urea, and glucose, and decreased total proteins and albumin levels. Cerebrospinal fluid analysis showed the presence of fibrin reticules and pleocytosis. Upon necropsy, longitudinal sections of the head revealed the presence of a nodular mass with a friable consistency and a white-yellowish coloration. Microscopic findings included meningitis, cortex necrosis and encephalitis with the presence of eosinophilic Splendore-Hoeppli substance. Histopathology of the lungs revealed a Splendore-Hoeppli-like material and hyperplasia of alveolar and bronchiolar epithelium. Renal lesions were suggestive of amyloidosis.
\end{abstract}

Key words: Conidiobolus coronatus, conidiobolomycosis, fungal diseases, upper respiratory system, entomophthomycosis, sheep.

\section{RESUMO}

O presente estudo objetivou relatar a ocorrência e os achados clínicos, laboratoriais, patológicos e micológicos de três surtos de conidiobolomicose rinocerebral e rinofaríngea em ovinos do estado do Rio Grande do Norte, Brasil. Um total de seis ovinos com sinais clínicos de conidiobolomicose foi avaliado, e informações sobre o histórico foram obtidas dos proprietários. Os sinais clínicos incluíram depressão, emaciação progressiva, descarga nasal serossanguinolenta, taquicardia, dispneia, miosite e exoftalmia unilateral com aumento do volume do globo ocular, ulceração da córnea e sinais nervosos. A principal alteração hematológica foi neutrofilia. A avaliação bioquímica sérica revelou aumento nos valores de AST, GGT, creatinina, ureia e glicose, e redução nos níveis de proteínas totais e albumina. A análise do fluido cerebrospinal revelou presença de retículos de fibrina e pleocitose. À necropsia, secções longitudinais da cabeça revelaram presença de uma massa nodular com consistência friável e coloração brancoamarelada. Os achados microscópicos incluíram meningite, necrose do córtex e encefalite com presença da substância eosinofílica de Splendore-Hoeppli. A histopatologia dos pulmões revelou uma substância similar à de SplendoreHoeppli e hiperplasia do epitélio alveolar e bronquiolar. As lesões renais foram sugestivas de amiloidose.

Palavras-chave: Conidiobolus coronatus, conidiobolomicose, doenças micóticas, sistema respiratório superior, entomoftomicose, ovino.

\section{INTRODUCTION}

Conidiobolomycosis is caused by fungi from the genus Conidiobolus, and it affects multiple species such as horses (STEIGER \& WILLIAMS, 2000), sheep (KETTERER et al.1992; RIET-CORREA, 2007) and humans (FISCHER et al., 2008). In sheep, three species were isolated from outbreaks: C. coronatus in Piauí,

'Universidade Federal Rural do Semi-Árido (UFERSA), Mossoró, RN, Brasil.

"Departamento de Ciências Animais, (UFERSA), BR 110, Km 47, 59625-900, Mossoró, RN, Brasil. E-mail: benito.blanco@pq.cnpq.br. Autor para correspondência. 
Northeastern Brazil (SILVA et al., 2007), C. lamprauges in Santa Catarina, Southern Brazil (FURLAN et al., 2010) and $\boldsymbol{C}$. incongruus in Australia (KETTERER et al., 1992).

Two clinical forms of the disease have been diagnosed. Rhinofacial conidiobolomycosis is characterized by swelling in the nasal vestibule and mucocutaneous union of the skin of the anterior part of the face and upper lip. In addition, nasal discharge and partly clogged nostrils are often observed, while the nasal mucosa and hard palate may be ulcerated. Clinical evolution can last for weeks, but some animals have been successfully treated (RIET-CORREA, 2007). The nasopharyngeal form of conidiobolomycosis affects the ethmoidal region, turbinates, paranasal sinuses, soft palate, orbit, pharynx, nearby muscles and local lymph nodes (RIET-CORREA, 2007; SILVA et al., 2007; RIET-CORREA et al., 2008). In this latter form, severe injury leads to exophthalmos and ocular lesions of the orbit, which are usually unilateral, and the eye is often swollen, opaque and exhibits corneal ulceration (SILVA et al., 2007; RIET-CORREA et al., 2008; BOABAID et al., 2008). The clinical course usually ranges from 7 to 15 days (RIET-CORREA, 2007); however, cases persisting up to 56 days have been reported (BOABAID et al., 2008).

Due to the lack of reports of conidiobolomycosis from the state of Rio Grande do Norte and due to the economic consequences from this highly lethal infection, the aim of this study were to report the occurrence and to describe the clinical, laboratory, pathological, and mycological findings of three outbreaks of rhinocerebral and rhinopharyngeal conidiobolomycosis in sheep from Brazil.

\section{MATERIALS AND METHODS}

Six sheep with conidiobolomycosis were clinically examined by the authors between June and October 2009, and dead animals were necropsied. Epidemiological data were obtained from ranchers. Blood samples were collected through jugular venipuncture in vacuum tubes with EDTA anticoagulant (10\%) for the complete blood count and determination of total plasma protein. Similar samples were collected without anticoagulant to obtain serum. Serum activity of enzymes, such as aspartate aminotransferase (AST), gamma glutamyltransferase (GGT) and alanine transferase (ALT), as well as the levels of urea, creatinine, cholesterol, glucose, total protein and albumin were determined using commercial kits (Katal, Belo Horizonte, MG) and an automatic analyzer SBA-2000 (Celm, Barueri, SP). The results of total protein and albumin levels were used for calculating levels of globulin and albumin/globulin $(\mathrm{A} / \mathrm{G})$ ratio. Samples of cerebrospinal fluid (CSF) were collected through cerebellar-medullary cisterns in three cases and analyzed according to previously described methodology (SCOTT, 1992). Conidiobolomycosis outbreaks occurred in three municipalities in the state of Rio Grande do Norte. The first one occurred in São Rafael. After clinical examination of three affected animals (Sheep 1, 2 and 3), infected sheep were taken to the Veterinary Hospital (HOVET) Section of Large Animals, Universidade Federal Rural do Semi-Árido (UFERSA), and a fourth animal (Sheep 4) was evaluated at the farm. The four sheep were females, Santa Ines mixed-breed, aging 1.5 to 6 years-old. Clinical data and disease evolution were obtained during a visit to the property at the time of the outbreak. The only two neighboring farms were also visited, and according to their owner's reports, similar cases had also occurred among sheep from their flocks. In the city of Campo Grande, conidiobolomycosis affected 12 sheep, and one of the affected animals, and adult Santa Ines mixed-breed female (Sheep 5), was taken for clinical examination. The last case (Sheep 6) occurred in Mossoró, Rio Grande do Norte state, where it affected a 6-year-old ram. The animal in this case died after a 28day clinical course with clinical signs of dyspnea and serosanguineous nasal discharge.

After spontaneous death or euthanasia in extremis, affected sheep were necropsied. Tissue fragments were collected from the ethmoidal region, nasopharynx, lungs, liver, kidneys, heart, gastrointestinal tract and central nervous system (CNS), which were fixed in buffered formalin $10 \%$, embedded in paraffin, sliced to a thickness of $5 \mu \mathrm{m}$ and stained with hematoxylin and eosin (HE). Fragments of brain and lung as well as masses from the nasopharyngeal region and the ethmoid bone were washed in sterile saline, macerated, plated on Sabouraud agar with chloramphenicol and incubated at $28^{\circ} \mathrm{C}$ for 7 days. Morphological characterization was performed using microculture techniques on slides that were stained with lactophenol-cotton blue and examined under 400x magnification, and identified according to HOOG \& GUARRO (1995).

\section{RESULTS}

Animals from the first outbreak (Sheep 1 to 3) came from a farm located in São Rafael. Upon visiting the property, it was found that the flock consisted of 110 sheep of different age groups that were raised semiintensively in areas of native pasture. During this visit, 
another sheep (Sheep 4) also presented the clinical profile of the disease, while the owner reported the recent death of another sheep after severe epistaxis. Thus, a total of 5 sheep $(4.54 \%)$ were affected by the infection on this farm. The clinical course varied from 3 to 30 days. Two neighboring properties also presented a clinical history of the disease during the same year, with similar clinical signs observed in two sheep from each farm, which had flocks of 10 (20\%) and $12(16.6 \%)$ animals, respectively. Three sheep from the first outbreak were unsuccessfully treated with sodium iodide ( $1 \mathrm{~g}$ intramuscularly for 5 days).

The second outbreak affected 12 sheep from a total of 150 animals on a farm located in Campo Grande. One of these animals (Sheep 5) was taken to Veterinary Hospital, UFERSA, and was clinically examined. During this outbreak, the onset of clinical signs occurred in August 2009, and the clinical course varied from 15 to 45 days; the last death was registered in October 2009. The flock was kept in a fenced native pasture with wetlands in the rainy season, which had received higher than the normal rainfall for the region during the year of the outbreak. Regarding the third outbreak, a single sheep (Sheep 6) was affected, which was intensively reared in the backyard of a property located in the urban area of Mossoró. Areas of excessive humidity and abundant organic matter were observed in this environment as well. All owners reported that the disease had not been observed in past years.

Respiratory signs (mixed dyspnea, respiratory sounds and sero- or mucosanguinolent nasal discharge), unilateral exophthalmos with hypopyon associated with corneal ulceration, blood accumulation in the sclera and swelling of the eyeball were the most frequent clinical signs. The clinical course was from 2 to 45 days. Other clinical signs included fever, miosis, blindness and ocular myiasis in two animals. Two sheep presented neurological signs, which included episodes of head movements that attempted to position the mandible with the sternum (Sheep 3) and lateral torsion of the head (Sheep 4).

In all sheep, the complete blood count revealed an inversion in the neutrophil:lymphocyte ratio and neutrophilic leukocytosis $(\mathrm{n}=3)$ with a regenerative left turn in two animals (Sheep 2 and 4). Regarding the red blood cells and plasma proteins, a normocytic normochromic anemia was diagnosed in Sheep 3, while Sheep 1 presented hypoproteinemia. All sheep had hypoalbuminemia, except Sheep 5. The other parameters were within physiological limits for the species. The serum biochemistry presented increased activity of AST and GGT enzymes, especially in Sheep 4 , as well as hyperglycemia in Sheep 1 and 3. The serum levels of urea and creatinine were elevated in three (Sheep 1, 2 and 5) and two (Sheep 2 and 3) animals, respectively. CSF exhibited a light yellowish, slightly cloudy appearance and the formation of fibrin reticulum and increased numbers of nucleated cells were observed in one animal (Sheep 2). In contrast, Sheep 3 presented formation of fibrin reticulum as the only change. The other parameters were within physiological limits for these sheep.

The main necropsy findings consisted of unilateral exophthalmos, sero- or mucosanguinolent nasal secretion and corneal opacity. Nodular masses, which were friable and yellowish-white in coloration, invaded and destroyed the turbinates, ethmoidal region, paranasal sinuses, soft palate and nasopharyngeal region (Figure 1) and were observed in the longitudinal head sections from all necropsied sheep. The lesion reached the cribriform plate and invaded the frontal cranial bone. At this point, there was a focus of osteolysis and an approximate $2 \mathrm{~cm}$ hole where the tumor was in contact with and penetrated the dura mater. An extensive focus of necrotic tissue of a blackish color and soft consistency with points of bleeding and suppuration was noticed in transverse sections of the brain of the referred animal, which specifically occurred in the region of the frontal and temporal cortex. A swelling of the parotid and retropharyngeal lymph nodes as well as purulent material was observed in Sheep 4. In Sheep 2, rounded nodules containing purulent material measuring $4 \times 3.5 \mathrm{~cm}$ in the diaphragmatic lobe of the lungs were noticed. Monocytes, macrophages, epithelioid cells and multinucleated giant cells surrounding SplendoreHoeppli eosinophilic substance (Figure 2A) were observed upon histological examination of the mass collected from the ethmoidal region. Meningoencephalitis (Sheep 3 and 6) and malacia (Sheep 3) were observed. Meningitis verified in these animals was characterized by intense infiltration of polymorphonuclear cells or lymphocytes and plasma cells (Figure 2B) as well as Splendore-Hoeppli eosinophilic substance. Also, macrophages containing hemosiderin were found. Regarding the affected location, the inflammatory infiltrate involved the meninges of the frontal and temporal cortex in Sheep 3 and the frontal lobe in sheep 6. Encephalitis (Figure $2 \mathrm{C}$ ) was evidenced by perivascular infiltrate composed of large perivascular cuffs formed by plasma cells, lymphocytes and Gitter cells in the gray matter of the frontal and parietal cortices in Sheep 3 and only in the frontal cortex in Sheep 6. The malacia was characterized by vacuolation of neuropil associated with the presence of densely infiltrated polymorphonuclear cells, 


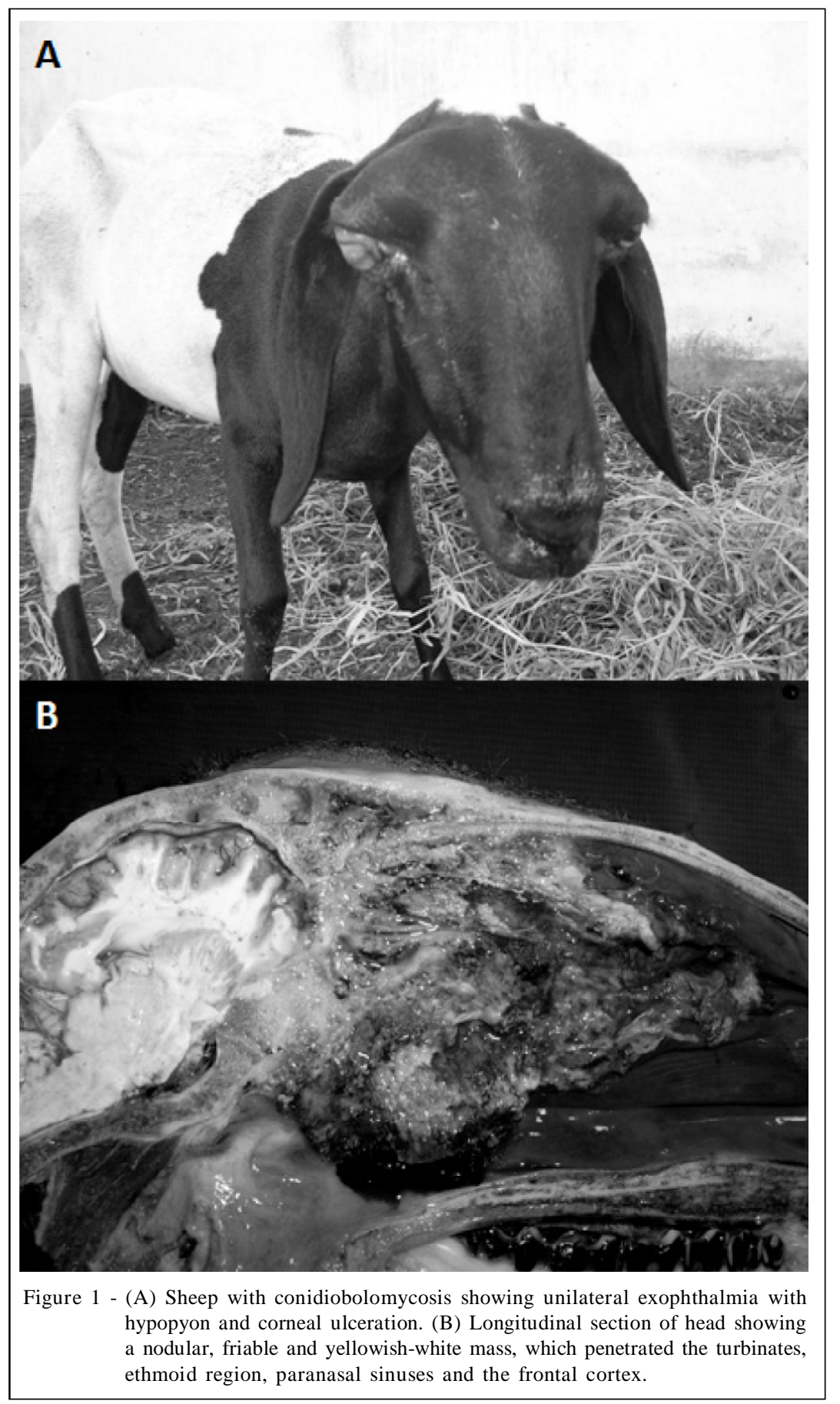

moderate amounts of Gitter cells (Figure 2D), lymphocytes, endothelial cell proliferation and Splendore-Hoeppli eosinophilic substance. There was also Splendore-Hoeppli type material, surrounded by polymorphonuclear cells, monocytes, macrophages and their derivatives (epithelioid cells and multinucleated giant cells). In addition, there was hyperplasia of the bronchiolar and alveolar epithelium with conjunctival proliferation and thickening of the interalveolar septa. Deposition of amorphous, homogeneous eosinophilic substance (suggestive of amyloidosis) was observed in glomeruli of the kidneys of those animals.

The growth of flat colonies with white grooves was observed after 7 days in cultures in Sabouraud agar with chloramphenicol. Hyphae, sporophores, primary spores with prominent papillary 


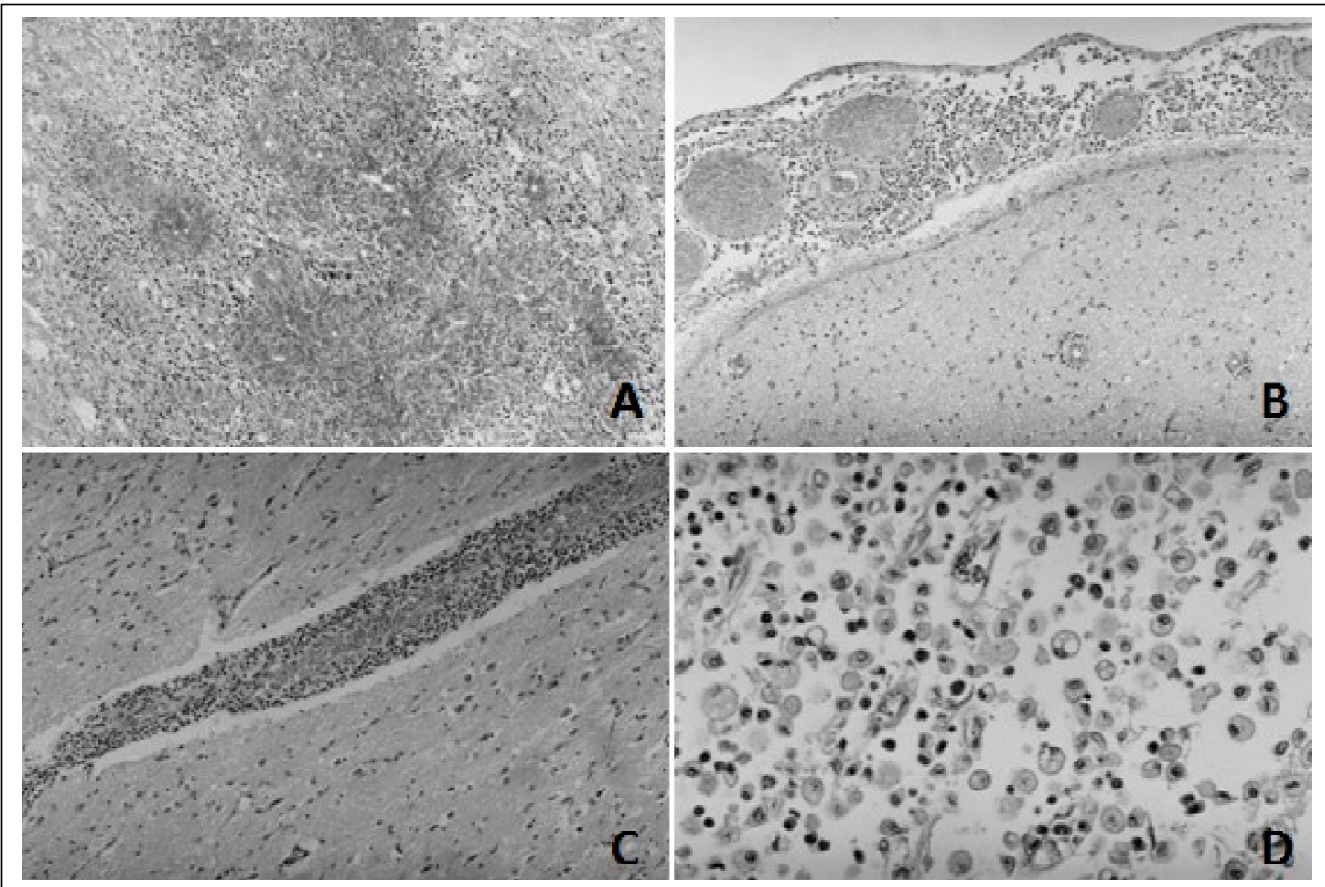

Figure 2 - SNC lesions sheep presenting conidiobolomycosis. A- Ethmoid region with Splendore-Hoeppli material surrounded by macrophage cells, epithelioid cells and multinucleated giant cells (HE, 20x). B- Lymphoplasmacytic meningitis in the frontal cortex (HE, 20x). C- Encephalitis in the frontal cortex with the presence of mononuclear perivascular inflammatory infiltrate (HE, 20x). D- Malacia of the frontal cortex with the presence of Gitter cells (HE, 40x).

basis and hair-like appendices (microspores) were observed in culture on slides stained with Lactophenolcotton blue. Based on these morphological aspects, the fungal mycelium was characterized as $C$. coronatus.

\section{DISCUSSION}

The diagnosis of these conidiobolomycosis outbreaks among these three cities in the state of Rio Grande do Norte, Northeastern Brazil was based on the association of epidemiological, clinical, pathological and mycological findings after isolation of $\boldsymbol{C}$. coronatus. Until this study, there had been no previous reports of conidiobolomycosis affecting sheep in Rio Grande do Norte state, Brazil. However, in 2009, there were three outbreaks totaling 22 cases of the disease. Six of these cases were examined and confirmed through fungal isolation. The reason for this unprecedented discrepancy may be explained by the high rainfall in 2009, which was atypical for this region. Importantly, the presence of high humidity, increased temperatures and large amount of decomposing vegetation are factors that favor the development of fungi and the formation of their reproductive structures (PRABHU \& PATEL, 2004). Consequently, there is a spreading in the environment of a high number of spores, which contaminate the grazing habits of sheep and predispose animals to infection via inhalation (RIET-CORREA et al., 2008). This factor was also supported by numerous other reports examining this disease (SILVAet al., 2007; BOABAID et al., 2008), while only a single 42-month ram was affected in the dry season (RIET-CORREA et al., 2008). The findings confirm past studies demonstrating that lesions caused by this class of fungi are painless, and the affected sheep do not present clinical signs until there are respiratory changes and/or exophthalmos with blindness (BOABAID et al., 2008; BATISTA et al., 2009).

Thus, as observed in other Brazilian states (SILVA et al., 2007; BOABAID et al., 2008; RIETCORREA et al., 2008), conidiobolomycosis imparts important economic impacts on the sheep industry due to the high lethality rate among infected animals (achieving 100\%). However, the successful treatment of two sheep in the initial course of the disease has been reported, which included a weekly dose of $100 \mathrm{mg}$ $\mathrm{kg}^{-1}$ sodium iodide intravenously (slow drip) for a total of four applications (XIMENES et al., 2007). The same dose was performed in this study with intervals of 24 
hours for a total of 5 applications via deep intramuscular injection. This regimen was unsuccessful even in sheep after 3 days of clinical course (Sheep 3).

The results of hematological evaluation were in agreement to previous studies (BATISTA et al., 2009). Biochemical evaluation of the serum revealed high activity for AST and GGT enzymes in all animals, which suggested liver damage. Moreover, the prolonged recumbency may have contributed to this increase in AST because of muscular injury (STOCKHAM \& SCOTT, 2002). These findings confirm earlier observations that this disease is able to promote some degree of hepatic dysfunction, imperceptible to clinical examination and complete blood count. There was an increase in the serum creatinine and urea, which did not differ from previous findings (BATISTA et al., 2009). The increased serum concentrations of urea and creatinine indicated injury to renal tissue (STOCKHAM \& SCOTT, 2002), which was confirmed through histopathology. The renal injury observed in this work suggested amyloidosis, which is a pathologic change rarely reported in ruminants. There are several pathophysiologic mechanisms that contribute to amyloidosis (ABBAS, 2005), but the most probable for the sheep evaluated in this research was the deposition of fibrillar amyloid protein (AA). It occurs in chronic inflammation with increased production of serum proteins associated with amyloid, which is an acute phase protein precursor of AA produced in the liver and is associated with circulating lipoproteins of the HDL3 subclass. Thus, conidiobolomycosis was responsible for significant renal injury, which was probably secondary to the underlying inflammatory processes which occurred in these animals.

Previous reported cases have presented nervous system injuries characterized by infiltrate with irregular whitish tissue in the olfactory bulb and the median longitudinal fissure of the brain (BOABAID et al., 2008). In the present report, one sheep had meningitis and necrosis in the frontal cortex, which extended to the temporal cortex. This animal also presented encephalitis with the presence of Splendore-Hoeppli eosinophilic substance. Such lesions in the CNS demonstrate the importance of $\boldsymbol{C}$. coronatus as a cause for these clinical and pathological manifestations. Indeed, fungal infections are sporadic causes of nervous system injury. Mycosis is acquired through inhalation of conidia, which tend to spread through the large vessels in a retrograde manner, being the nasal cavity and paranasal sinuses most commonly affected.

The evaluation of CSF is a valuable diagnostic tool for CNS diseases in live animals. In fact, pleocytosis is associated with infectious diseases, lymphocytic CSF is associated with viral diseases, neutrophilic CSF is associated with acute bacterial infections and monocytic CSF is associated with chronic bacterial infections. Moreover, CSF usually appears unchanged in toxic, metabolic, degenerative and neoplastic diseases (STOKOL et al., 2009). Among the animals examined in this research, two sheep presented fibrin lattices, and one of these was also associated with pleocytosis. Thus, evaluation of CSF should be recommended for determining CNS involvement in conidiobolomycosis. It is worth emphasizing the importance of not allowing blood contamination of the CSF because such a mistake could change the composition of the CSF, especially the protein concentration and cellularity (DOYLE \& SOLANO-GALLEGO, 2009).

In Northeastern Brazil, a differential diagnose must be made from a disease promoting very similar clinical signs as granulotous rhinitis promoted by Pythium insidiosum (SANTURIO et al., 2008), whilst enzootic nasal adenocarcinoma of sheep is diagnosed in many countries of Europe (SVARA et al., 2006). The isolation of $\boldsymbol{C}$. coronatus was crucial to confirm the presumptive diagnosis. This same species has been identified as being responsible for previous outbreaks in sheep (SILVA et al., 2007), while C. lamprauges was shown to be the responsible species in Santa Catarina, Southern Brazil (FURLAN et al., 2010) and $\boldsymbol{C}$. incongruus in Australia (KETTERER et al., 1992).

Therefore, this is the first report of conidiobolomycosis in the state of Rio Grande do Norte, Northeastern Brazil. The diagnosis of these outbreaks was based on the association of epidemiological, clinical, pathological and mycological findings after isolation of $\boldsymbol{C}$. coronatus.

\section{REFERENCES}

ABBAS, A.K. Diseases of the immune system. In: KUMAR, V. et al. Robbins \& Cotran pathologic basis of disease. 7.ed. Philadelphia: Elsevier Saunders, 2005. p.203-280.

BATISTA, M.C.S. et al. Hemograma, proteinograma, ionograma e dosagens bioquímicas e enzimáticas de ovinos acometidos de conidiobolomicose no Nordeste do Brasil. Pesquisa Veterinária Brasileira, v.29, p.17-24. 2009. Available from: <http:// www.scielo.br/scielo.php?script=sci_arttext \&pid=S0100736X2009000100002\&lng=en\&nrm=iso>. Accessed: Dec. 10, 2010. doi: 10.1590/S0100-736X2009000100002.

BOABAID, F.M. et al. Conidiobolomicose em ovinos no Estado de Mato Grosso. Pesquisa Veterinária Brasileira, v.28, p.77-81, 2008. Available from: <http://www.scielo.br/ s cie lo.ph p s c ri pt $=$ s c i_art text \& pid=S $0100-$ 736X2008000100012\&lng=en\&nrm=iso>. Accessed: Dec. 10, 2010. doi: 10.1590/S0100-736X2008000100012. 
DOYLE, C.; SOLANO-GALLEGO, L. Cytologic interpretation of canine cerebrospinal fluid samples with low total nucleated cell concentration, with and without blood contamination. Veterinary Clinical Pathology, v.38, p.392-396, 2009. Available from: <http://onlinelibrary.wiley.com/doi/10.1111/ j.1939-165X.2009.00132.x/abstract>. Accessed: Dec. 10, 2010. doi: 10.1111/j.1939-165X.2009.00132.x.

FISCHER, N. et al. Rhinofacial Conidiobolus coronatus infection presenting with nasal enlargement. Infection, v.36, p.594-596, 2008. Available from: <http://www.springerlink.com/content/ b765068g3219258p/>. Accessed: Dec. 10, 2010. doi: 10.1007/ s15010-008-8056-5.

FURLAN et al. Conidiobolomicose causada por Conidiobolus lamprauges em ovinos no Estado de Santa Catarina. Pesquisa Veterinária Brasileira, v.30, p.529-532, 2010. Available from: $<$ http://www.scielo.br/scielo.php?script=sci_arttest\&pid=S0100736X20100000700003\&lng=en\&nrm=iso>. Accessed: Dec. 10, 2010. doi: 10.1590/S0100-736X20100000700003.

HOOG, G.S.; GUARRO, J. Atlas of clinical fungi. 2.ed. Baarn: Centraalbureau voor Schimmelcultures, 1995. 720p.

KETTERER, P.J. et al. Rhinocerebral and nasal zygomycosis in sheep caused by Conidiobolus incongruous. Australian Veterinary Journal, v.69, p.85-87, 1992.

PRABHU, R.M.; PATEL, R. Mucormycosis and entomophthoramycosis: a review of the clinical manifestations, diagnosis and treatment. Clinical Microbiology and Infection, v.10, p.31-47, 2004. Available from: <http:// onlinelibrary.wiley.com/doi/ $10.1111 /$ j. 1470 9465.2004.00843.x/abstract>. Accessed: Dec. 10, 2010. doi: 10.1111/j.1470-9465.2004.00843.x.

RIET-CORREA, F. Conidiobolomicose em ovinos. In: RIETCORREA, F. et al. Doenças dos ruminantes e eqüinos. 3.ed. Santa Maria, Palloti, 2007. p.448-450.

RIET-CORREA, F et al. Outbreaks of rhinofacial and rhinopharyngeal zygomycosis in sheep in Paraíba, northeastern Brazil. Pesquisa Veterinária Brasileira, v.28, p.29-35, 2008. Available from: <http:/ /www.scielo.br/scielo.php?script $=$ sci_arttext $\&$ pid $=S 0100-$ 736X2008000100005\&lng=en\&nrm=iso>. Accessed: Dec. 10, 2010. doi: 10.1590/S0100-736X2008000100005.

SANTURIO, J.M. et al. Granulomatous rinitis associated with Pythium insidiosum infection in sheep. Veterinary Record, v.163, p.276-277, 2008. Available from: <http:// veterinaryrecord.bmj.com/content/163/9/276.extract $>$. Accessed: Fev. 4, 2011. doi: 10.1136/vr.163.9.276.

SCOTT, P.R. Analysis of cerebrospinal fluid from field cases of some common ovine neurological diseases. British Veterinary Journal, v.148, p.15-22, 1992. Disponível em: <http:// www.sciencedirect.com/science?_ob=ArticleURL\&_udi=B7RMC4 MCXM8Y-5\&_user $=687358 \&$ _coverDate $=02 \% 2$ F $29 \% 2$ F 19 $92 \&$ _rdoc $=1 \&$ \&mt $=$ high $\&$ _orig $=$ gateway $\&$ _origin=gatew ay $\&$ _sort $=$ d\&_docanchor $=\&$ view $=c \&$ \&searchStrId $=1738$ $020284 \&$ \& rerunOrigin $=$ google \&_a c c t $=$ C 000 $037899 \&$ \& version $=1 \&$ \&_urlVersion $=0 \&$ \& userid $=$ $687358 \&$ m d $5=466475$ b 5708 c 27 f 3 e 2 c 91 e $273 \mathrm{db} 97773 \&$ searchtype $=\mathrm{a}>$ doi:10.1016/0007-1935(92)90062-6.

SILVA, S.M.M.S. et al. Conidiobolomycosis in sheep in Brazil. Veterinary Pathology, v.44, p.314-319, 2007. Available from: <http://vet.sagepub.com/content/44/3/314.full>. Accessed: Dec. 10, 2010. doi: 10.1354/vp.44-3-314.

STEIGER, R.; WILLIAMS, M.A. Granulomatous tracheitis caused by Conidiobolus coronatus in a horse. Journal of Veterinary Internal Medicine, v.14, p.311-314, 2000. Available from: <http://onlinelibrary.wiley.com/doi/10.1111/ j.1939-1676.2000.tb01172.x/abstract>. Accessed: Dec. 10, 2010. doi: 10.1111/j.1939-1676.2000.tb01172.x.

STOCKHAM, S.L.; SCOTT, M.A. Fundamentals of veterinary clinical pathology. Ames: Blackwell, 2002. 640p.

STOKOL, T. et al. Cerebrospinal fluid findings in cattle with central nervous system disorders: a retrospective study of 102 cases (1990-2008). Veterinary Clinical Pathology, v.38, p.103-112, 2009. Available from: <http://onlinelibrary.wiley.com/ doi/10.1111/j.1939-165X.2008.00094.x/abstract>. Accessed: Dec. 10, 2010. doi: 10.1111/j.1939-165X.2008.00094.x.

SVARA, T. et al. Enzootic nasal adenocarcinoma of sheep. Slovenian Veterinary Research, v.43, n.2, p.71-75, 2006.

XIMENES, F.H.B. et al. Efeitos de iodeto de sódio por via endovenosa no tratamento de zigomicose em ovinos. Archives of Veterinary Science, v.12, supl, p.242-243, 2007. Available from: <http://ojs.c3sl.ufpr.br/ojs2/index.php/veterinary/article/ download/11153/7651>. Accessed: Dec. 10, 2010. 